\title{
IS THE CATHOLIC CHURCH A SAFE SPACE FOR RELIGIOUS SISTERS? \\ CHARTING THE AFRICAN TERRAIN USING THREE CASE STUDIES
}

\author{
Chika Eze \\ School of Applied Human Sciences (Psychology) \\ University of KwaZulu-Natal \\ CG Lindegger \\ School of Applied Human Sciences (Psychology) \\ University of KwaZulu-Natal \\ Susan Rakoczy \\ School of Religion, Philosophy and Classics \\ University of KwaZulu-Natal
}

\begin{abstract}
The Congregation for the Doctrine of the Faith from the Vatican asked the Leadership Conference of Women Religious in the US on 18 April 2012 to revise and place itself under the control of an archbishop. ${ }^{l}$ To date, there have been unsolicited visitations from the Vatican to the same religious women in the US from 2009-2011. ${ }^{2}$ These events are examples of de facto gender-based discrimination within the Catholic Church, which stultify religious sisters by the Church's hierarchies, and prompt the question: 'Is the Catholic Church a safe space for religious sisters?'This article uses a historical review to trace the trajectory of religious sisters in the Catholic Church across the ages to the present, in an attempt to analyze how sisters have been/are being constructed in the Church. Using feminist anthropology, the article analyzes various Church documents which show how women's identities have been constructed. The analysis includes examining how the sisters also construct 'who they are' in the different eras of the Church's life. In addition, profiles of three African religious sisters are used as case studies to argue that through personal agency and education, sisters have negotiated and constructed the Church's space into safe space.
\end{abstract}

Key Words: Catholic Church; Safe Space; Religious Sisters; Church Hierarchy; Gender-base Discrimination; Personal Agency

Joshua J McElwee, "Vatican-criticized nun addresses fellow theologians", National Catholic Reporter, http://NCRonline.org (accessed 10-06-12).

2 Sandra Schneiders, IHM, Prophets in their own country: Women religious bearing witness to the Gospel in a troubled Church. New York: Orbis Books (2011). 


\section{Introduction}

Catholic religious sisters are a cohort of women who feel called by God and they respond by dedicating their entire lives to the service of God and humanity. ${ }^{3}$ According to the Church's doctrine, these religious sisters live a religious life known as consecrated life. This is a form of life defined as belonging to the life of the laity of the Church. ${ }^{4}$ On the one hand, the Second Vatican Council asserted that "this form of life has its own place in relation to the divine and hierarchical structure of the Church," $" 5$ but on the other hand, it maintains that "the state of life... which is constituted by the profession of the evangelical counsels, while not entering into the hierarchical structure of the Church, belongs undeniably to her life and holiness." This kind of discourse has a number of implications; the religious are explicitly excluded from the Church's hierarchical structure which in itself is not the problem. The issue is that men and women live a religious life, but in reality, women who feel called by God to devote their life to the Church's ministry and service are stifled by the Church's doctrinal teachings that women are excluded from the ministerial priesthood, on the grounds that only males can act in persona Christi. ${ }^{7}$ As women, they can only be admitted to the religious form of life which falls outside the ordained ministry of the Church that constitutes the Church's hierarchy. ${ }^{8}$ Recently, Pope Francis reiterated that the discussion on women's ordination in the Catholic Church is closed, he rather advocates that a further theology of women needed to be done. ${ }^{9}$ In this way, women have limited space in terms of ministry within the Church; they are not members of the Church's hierarchy.

Although, there is evidence that in the early Church women had served as deacons, ${ }^{10}$ the office of women diaconate was discontinued in the West in the fourth century and about the ninth century in the East. ${ }^{11}$ This discontinuation is based on 'kyriarchal theology' which can best be described as theology of the fathers, which is androcentric. ${ }^{12}$ On this basis, religious women are often constrained to have limited space within which they can minister in the Church. Unpacking the history of women in the Church reveals that women, particularly religious sisters, have been subjected to subordinate positions by the male hierarchies of the Church which has continued to the present day. Using the lens of feminist theological anthropology, I will review the subservient positions to which women (sisters) have been conditioned in the early Church, the medieval period, pre-Vatican II and postVatican II era to the present $21^{\text {st }}$ century. Also, attention will be paid to how women have

3 Decree on the up-to-date renewal of religious life, Perfectae Caritatis in Vatican Council II: The Council Post Conciliar Documents, ed. A Flannery. New Delhi: St Pauls, (1975:1).

4 Dogmatic Constitution on the Church, Lumen Gentium in Vatican II: In The Council Post Counciliar Documents, ed. A Flannery. New Delhi: St Pauls, (1975:44).

Lumen Gentium, Vatican II, 43.

Lumen Gentium, Vatican II, 44.

Papal Encyclical, Inter Insigniores: Declaration on the question of admission of women to the ministerial priesthood, (1976), 5.

8 Lumen Gentium, Vatican II, 44.

9 Ivone Gebara, (English translation by Rebel Girl) Pope Francis and the Theology of Women: Some Concerns. Iglesia Descalza http://iglesiadescalza.blogspot.fr/2013/08/pope-francis-and-theology-of-women-some.html (accessed on 12-08-2013).

10 John Wijngaards, Women Deacons in the early Church: Historical Texts and Contemporary Debates. New York: The Cross Road Publishing Company, (2006), 11.

11 Susan Rakoczy, IHM, In Her Name: Women doing Theology. Pietermaritzburg: Cluster Publications, (2004:233).

12 Elizabeth Schüssler Fiorenza, In memory of her: A feminist theological reconstruction of Christian origins. New York: Crossroad (1983), 55; Rakoczy, In her Name, 208. 
negotiated these positions in an attempt to overcome the limitations imposed on them. Life stories of three African religious sisters will be used as case studies to argue that through personal responsibility and engagement with education, women (sisters) could counteract and make the Church a space safe space for themselves and others.

\section{The Catholic Church's Traditional Gender Construction of Women}

Analyzing the early Catholic Church's gender discourse and practice, one would be inclined to conclude that the Church provides women with no safe space for selfconstruction. By safe space, this article refers specifically to the Church's structure which has defined as well as position women as inactive regarding the Church's hierarchy. The early Fathers of the Church used defamatory language to describe women, thereby not only projecting a negative image of women but also presenting them as a group that should be kept under control. ${ }^{13}$ Directly or indirectly, the Church's gender constructs impact on women's self-construction and participation within the Church space and the society at large.

A leading proponent of such defamatory constructs is Tertullian (c.160-c.220 AD) who defined women as "the gateway of the devil." 14 Moreover, he argues that it is not permitted for women "to speak in the Church, to teach, to baptize, to sacrifice, to fulfill any other male function, or to claim any form of priestly functions." ${ }^{15}$ Likewise, Origen (185-254 AD) posits that "women had been prophets, but stresses that they did not speak publicly and especially not in the worship assembly of the Church."16 St Augustine of Hippo (c. 354-430) strongly argues that "the woman together with the man is the image of God... But when she is assigned as a helpmate... she is not the image of God: however, in what pertains to man alone, is the image of God just as fully and completely as he is joined with the woman into one."17 These are some of the ways in which women have been defined based on the cultural lenses of Judeo-Greek and Roman traditions that position women as subordinates to men. ${ }^{18}$ Based on such descriptions, women are relegated to the background; especially religious women who feel called in the same way as men to the service of God and humanity.

In spite of such constructions, women in the early Church did not relent. They went ahead forging safe spaces for themselves. For example, the Church's historical origin of religious life is traced to the lives of consecrated virgins and widows in the first century. ${ }^{19}$

13 Elizabeth Schüssler Fiorenza, The power of naming: A Concilium reader in feminist liberation theology. New York: Orbis Books (1996), 165.

Fiorenza, In memory of her, 55.

Coyle, cited in Fiorenza, In her memory, 55.

Fiorenza, In memory of her, 54.

7 Maureen McKew, "Augustine on women: De Trinitate, 12, 7, 10"

heritage.villanova.edu/vu/heritage/allthings/2001SU.htm (accessed on 04-07-12).

18 Hans Küng, Women in Christianity. London: Continuum (2001); Teresa Okure, What the African Synod means for religious communities in Africa/Madagascar: In reference to reconciliation, justice and peace. A talk delivered to Clung sisters during chapter gathering (2010) 10; Ngozi Uti, Come, let us talk this over: On the condition of women religious in the Church. In AE Orobator (ed.) Reconciliation, justice, and peace: The second African synod. Nairobi, Kenya: Acton Publisher (2011).

19 N Brockman, A popular history of religious life. Nairobi, Kenya: St Paul Publications (1990); JAK McNamara, Sisters in arms: Catholic nuns through two millennia. Cambridge, Mass: Harvard University Press (1996); Diarmuid O’Murchu, Religious Life: A prophetic vision-hope and promise for tomorrow. Notre 
Although this historical fact is often replaced by later development of a monastic form of religious life in the second century in the East (Egypt) initiated particularly by men. ${ }^{20}$ In reality, it is these virgins and widows who are the pioneers that ignited the rich foundation of Catholic religious life. Early Christians understood virginity as a spiritual state, ${ }^{21}$ for instance, the four daughters of Philip the Deacon lived as consecrated virgins. ${ }^{22}$ Therefore, women have not in any way agreed to be passive in the face of the Church's delimited space; neither have they approved the use of defamatory language to describe who they are.

\section{The Medieval Era and the Church's Construction of Women}

During the high middle ages, the anti-women movement in the Church reached its peak with St Thomas Aquinas arguing that the female sex is misbegotten male and, therefore, women were inferior by nature to men. ${ }^{23}$ To some extent, Thomas's description of women were founded on the flawed anthropological understanding of women prevalent in that era ${ }^{24}$ of which Aristotle and Plato's misogynist constructs of women were disparaging and used to discredit women. Aristotle in his writings projected that "the male is by nature superior, and the female inferior; and the one rules and the other is ruled; this principle, of necessity extends to all mankind." ${ }^{, 5}$ Sadly, many Church fathers have fallen into the same guilt of constructing women as not only subordinate to men but also as a problem that needs to be addressed. ${ }^{26}$ For example, religious sisters between the thirteenth and sixteenth centuries were forced into living the cloistered form of religious life. ${ }^{27}$ The cloistered form of religious life was a structure put in place by the male hierarchies of the Church to keep women religious enclosed within the walls of their convent; in so doing, they had minimal contact with the world outside. ${ }^{28}$ But religious sisters of this era took up different strategies in order to combat being cloistered and sometimes achieved this goal in collaboration with some clergy who helped to defend their cause. ${ }^{29}$ For instance, in order to resist the cloistered form of religious life during these centuries, many religious women became founders starting their own congregations as Oblates, Ladies of Charity, Third Orders, and Confraternities. ${ }^{30}$ Notable among such beginnings were the Ursulines founded by Angela

Dame, Indiana: Ave Maria Press (1991); Sandra Schneiders, IHM, Finding the treasure: Locating Catholic religious life in a new ecclesial and cultural context. New Jersey: Pauline Publications (2000).

RA Boever, Cameos of Church History. Ligouri, Missouri: Liguori Publications (1986); Martin O'Reilly, The challenges of being a religious in Africa. Kenya: Kolbe Press (1996).

Brockman, A popular history of religious life, 25; McNamara, Sisters in arms.

Acts of the Apostles 21:8.

ST I, 92, al: St Thomas Aquinas Parish Citronelle, AL 36522.

www.parishesonline.com/scripts/HostedSites/org.asp.asp?=5\&ID...(Accessed on 23-09-12).

4 Fiorenza, The power of naming.

25 Michelle Gonzalez, Created in God's image: An introduction to feminist theological anthropology. New York: Orbis Books (2007:22).

26 Küng, Women in Christianity.

27 Po-Chia Hisa, R, The World of Catholic Renewal 1540-1770. Cambridge: Cambridge University Press (1998:139).

28 Leslie Tuttle, "From cloister to court: Nuns and the gendered culture of disputing in early modern France." Journal of Women's History 22, (2) (Summer 2010:1-42).

29 Abbot, Elizabeth, A History of Celibacy. New York: Harper Collins Publishers LTD (1999); SM Maloney, "Historical perspective on women religious: Implications for creating a feminist theology of religious life." In Women \& Theology, In MA Hinsdale and PH Kaminski (eds.) 184-200. Maryknoll, New York: Orbis Books, 1995.

30 Schneiders, IHM, Finding the Treasure: 294. 
Merici and the Daughters of Charity co-founded by St Vincent and Louise de Marillac to mention but two.

Sadly though, some women who challenged the male hierarchies within this era were burnt at the stake for heresy. Such was the case of Marguerite Porete (died 1310), a French mystic and the author of The Mirror of the Souls. ${ }^{31}$ St Joan of Arc (1412-1431) was burnt also at the stake for mingling with male politics. ${ }^{32}$ Twenty-five years after her execution, an inquisitorial court authorized by Pope Callixtus III examined the trial, pronounced her innocent, and declared her a martyr. ${ }^{33}$ St Teresa of Avila (1515-1582) was investigated by 'Inquisition' (Church body which today can be described as the Congregation of the Doctrine of Faith) for her writings, which were held back by Dominican Domingo Báñez on the account that "it is not fitting that writings by women be made public." ${ }^{34}$ Her writings were posthumously published and she was canonized a saint in 1622, and in 1970, declared a Doctor of the Church based on her writings and teachings on prayer - a rare privilege for a woman. There are three women who have been honoured in this way too: Catherine of Siena (1347-1380), St Thérèsa of Lisieux (1873-1897) and St Teresa of Avila. As recent as October 2012, Pope Benedict XVI canonized the fourth woman doctor of the Church, Hildegard of Bingen (1098-1179). ${ }^{35}$ This proves that women made outstanding contributions even though they were constrained to do so from behind the scenes because they were restricted from operating within the Church's public space.

\section{Pre-Vatican II Era and Religious Women}

From an anthropological and a theological perspective, the question regarding the Catholic Church as a safe space for women, particularly for religious sisters before the 1960s, was elusive. This is based on the many pronouncements of the Church and encyclicals of the Popes which often addressed women's roles and duties as wives and mothers, and only rarely ventured into their lives outside the home. ${ }^{36}$ Scrutinizing the Popes' encyclicals, particularly those of Pope Leo XIII's Arcanum divinae sapientiae, Rerum novarum and Pope Pius XI's Casti connubii, there is evidence that the church focused its attention on women as wives and mothers. For example, Pope Leo XIII in his encyclical, Arcanum divinae sapientiae prioritized the role of women in marriage (February 10, 1880); a few years later, he published Rerum novarum in which he made an attempt to specifically address women as a class of workers (May 15, 1891). But what did it say? It reads:

Finally, work which is quite suitable for a strong man cannot rightly be required from a woman or a child... Women again are not suited for certain occupations; a woman is by nature fitted for home-work, and it is that which is best adapted at once to preserve her modesty and to promote the good bringing up of children and the well-being of the family. 37

\footnotetext{
31 Marguerite Porete - The mirror of simple souls. (accessed on 15-08-2012) www.margueriteporette.org/ Abbot, A History of Celibacy: 24.

Joan of Arc, Brief Biography. archive.joan-of-arc.org/joanofarc_short_biography.html (Accessed on 15-08-12).

34 Po-Chia Hisa, The world of Catholic renewal: 139.

35 Pope to canonize and name Hildegard of Bingen as Doctor of the ... www.romereports.com/.../pope-to-canonize-and-name-h...- United States (accessed on 08-09-12).

36 Ivy A Helman, Women and the Vatican: An exploration of official documents. New York: Orbis Books (2012:1).

37 Rerum novarum, paragraph 42 cited in Helman, Women and the Vatican: 17
} 
Based on this promulgation, the Church acknowledges that women have entered the public workplace but on the grounds of gender and natural reasons they should be given duties that are in accordance with their nature. It seems the Church has always constructed this 'in-house activity' for women as divinely assigned, thus they are to be perpetually restricted and resigned to protecting and caring for the family, and this cannot be altered. ${ }^{38}$

Pope Pius XI carried on in the same manner when he published Casti connubii, an encyclical on Christian marriage, on 31 December 1930. Interestingly, paragraph 76 declares that there is a certain inequality between men and women which is natural and for the good order of society, the home, and the family. In fact, the document spelt it out that the idea of women's emancipation from motherhood in an effort to be equal to men in politics, in economics, and social relations is criminal and will only lead women to be treated as slaves and property of men. ${ }^{39}$ On a parallel footing, women religious of this era were not constructed differently. There were restrictions which limited their activities and their access to higher education; their contributions in the Church were not given recognition. In extremely remarkable ways, many religious women of this era became founders in their own right: they built schools and hospitals as strategies to combat the long history of sheltered and cloistered form of religious life. However, some of these founders conflicted with the Church hierarchies on many fronts - particularly in securing approval for their constitutions. The Prefect of Propaganda Fide (usually male clerics from the Vatican) approves congregational constitutions without which the order remains unofficial. For example, Cornelia Connelly, the founder of the Society of the Holy Child Jesus had to stridently stand her ground from 1846-1870 to have her constitutions approved. ${ }^{40}$ Likewise Margaret Ann Cusack (1832-1899), the founder of Sisters of St Joseph of Peace, chose to leave the Catholic Church following continuous altercation with her bishop, yet the congregation she founded continues to date. ${ }^{41}$

\section{Post-Vatican II Gender Idea of Women}

From the 1960s onward, the Roman Catholic Church began to develop a more thorough understanding of women and their role in the family, their rising, socially, politically, and their economic status. ${ }^{42}$ The Vatican II Council of 1962-65 influenced the Church's shifted position regarding the way women have been constructed. The Council had a groundbreaking effect which challenged the Church to review its relationships on many fronts, including how women were being treated. There are other opinions stating that the Church's improved recognition of women's status was impacted upon by the historical development of the different waves of feminism that was taking place during this era Therefore, the Church could not afford to look on passively but join the transformation that was happening in the society at large and therefore (taken off) to accord women some respect. ${ }^{43}$ However, the important thing is that the Church moved a step forward in

\footnotetext{
38 Rosemary Radford Ruether, Contemporary Roman Catholicism Crises and Challenges. Kansas City, MO: Sheed and Ward (1987)

39 Helman, Women and the Vatican: interpretation of paragraph 74-5 of Pope Pius XI's encyclical.

40 Yes, Lord, always yes: A life of Cornelia Connelly, Founder of the Society of the Holy Child Jesus, 1809-1879.

41 Congregation of the sisters of St Joseph of Peace-history and... www.csjp.org/roots/historyfounder.html (accessed 15-10-12).

42 Helman, Women and the Vatican: 21; Ruether, Contemporary Roman Catholicism:34.

43 Helman, Women and the Vatican: 19; Sherry Ortner, cited in Rosemary Radford Ruether, Sexism and GodTalk: Towards a feminist theology. London: SCM Press (1983:72-5).
} 
according women some recognition in terms of their worth as human persons created in the image of God Thus, they are part of that family that make up the body of Christ in God. ${ }^{44}$ At the end of the Council in 1965, Pope Paul VI specifically addressed women as follows:

And now it is you that we address ourselves, women of all states - girls, wives, mothers and widows, to you also, consecrated virgins and women living alone - you constitute half of the immense human family. As you know, the Church is proud to have glorified and liberated woman, and in the course of the centuries, in diversity of characters, to have brought into relief her basic equality with man. But the hour is coming, in fact has come, when the vocation of woman is being achieved in its fullness, the hour in which woman acquires in the world an influence, an effect and a power never hitherto achieved. That is why, at this moment when the human race is under-going so deep a transformation, women impregnated with the spirit of the Gospel can do so much to aid mankind in not falling. 45

The Pope in this address not only recognized the dignity of women but also invited them to do their part constructively in making the world a better place. This invitation was reechoed by Pope John Paul II who in 1988 reinterpreted those biblical texts that are often used to advance the subjugation of women, such as Gen. 2:18-25; Eph. 5:21-33 and as such advocates that the Genesis creation account should be interpreted to reflect the divine image in women. ${ }^{46}$ At the dawn of the millennium, John Paul II again, in his encyclical Novo millennio ineunte continued to invite the Church, both men and women to go back to the original priority of using Christ's lens as the measure for relationships, and participation in the Church and the society at large. ${ }^{47}$ In this way, all members of the Church (including men, women, boys, girls and infants) are invited to share in the identity of Christ which is the highest form of human identity which legitimates their full membership and active participation. ${ }^{48}$ As a consequence, no one should be excluded from either reaching the highest development for which they have the ability, or rendering service in the different ministries of the Church.

Conversely, there seems to be a dissonance between the Church's theory and practice regarding women's full realization of their vocation as human persons who share equality with men hierarchies in the Church, particularly when it comes to religious sisters who are called by God to devote their entire life to the service of God and humanity. Starting from the Vatican II Council of 1962-65 (50 years ago), this dissonance played itself out: there was no women representation at the beginning of the Council. ${ }^{49}$ Half way through the Council, Cardinal Suenens of Belgium challenged his fellow bishops asking: "why are we even discussing the reality of the Church when half of the Church is not even represented

44 Pastoral Constitution on the Church in the Modern World: Gaudium et Spes. In The Council Post Conciliar Documents, ed. A Flannery. New Delhi: St Pauls, (1975:29).

45 Pope Paul VI's address to women, 8 December 1965. In Helman, Women and the Vatican:30

46 Pope John Paul II: Apostolic letter, Mulieris Dignitatem of John Paul 11-Dignity and Vocation of Women. Kenya, Paulines Publications Africa (2005:1).

47 Apostolic Letter, Novo Millennion Ineunte of his Holiness Pope John Paul II to the Bishops Clergy and lay Faithful. (6 January 2001) www.vatican.va/.../john_paul_ii/.../hf_jp-ii_apl_20010106_novo-mil... (accessed 07-08-2012).

48 This is based on the concept of 'imago Dei' (cf. Jn 1:18, Col 1:15) which was proposed by women theologians. That understanding that the human being's highest identity originates from a covenant relationship with God through Christ.

49 Carmel McEnroy, 1996. Guests in their own house: the women of Vatican II. New York: Crossroad Publishing Company (p. 45). 
here?" 50 This provocative question prompted the Council to invite a few more women to the second half of its meeting. Mary Luke Tobin, SL, the president of the Conference of US Major Superiors of Women then (now known as the Leadership Conference of Women Religious), a participant at the Vatican Council, describes women's participation at the Council as a "tiny crack in the door" in recognition of the vast indifference to women and of their potential for the whole body of the Church. ${ }^{51}$ The number of women was insignificant considering the population of women in the Church. Moreover, their participation was on the periphery - they were merely auditors. Notably, there were ten religious sisters who were part of the 23 auditors, but Cardinal Antoniutti who chaired the commission on Perfectae Caritatis (the commission that worked on up-date renewal of religious life) refused to allow women auditors' participation in his commission. ${ }^{52}$ This made it impossible for religious sisters to participate in the discussion that directly affected their daily lives, yet the numbers of women who live a religious life outnumber men.

Implicitly or explicitly, women's participation and recognition in the Church have always been presented on solicited grounds. The Catholic Church has clearly declared that in spite of sharing equality as children of God, women must keep away from aspiring to the ministerial priesthood, which is the sole prerogative of the male. ${ }^{53}$ The male Church hierarchy argues that it is a tradition handed down to them by Jesus Christ, himself, by his choice of choosing twelve male disciples; as such she has no authority to alter what the Lord himself has instituted. In the 1990s, the Catholic Church went so far in two documents as to express its position regarding women's ordination: Ordinatio Sacerdotalis, which declares that the Church lacks the authority to ordain women and requires the full assent of the faithful to this declaration. ${ }^{54}$ A follow-up document, Responsum ad propositumdubium declares that Ordinatio Sacerdotalis is infallible. Consequentially, women of all class including religious sisters should stay clear from conceiving in their minds a call to the priesthood or full participation in the Church's hierarchal positions. In August 2013, Pope Francis maintains that the service of women in the Church flows from the example of the Virgin Mary, which is more superior to that of the apostles - therefore, no need to long for a different space for women. ${ }^{55}$ Thus, he declares the dialogue for women ordination in the Catholic Church a closed conversation. On 18 September 2013 an Australian Catholic priest who advocates for women ordination was excommunicated. ${ }^{56}$ This recent excommunication proves that the issue of women ordination is unthinkable for the Church. The good news is that from time to time, women including religious sisters are called to participate in the events/activities of the church's hierarchy, such as was, in the case of the African Special Synod of Catholic Bishops in 2009, when 30 women were invited to participate among 344 participants. The different bishops' conferences in Africa and in the universal Church - when they deem it suitable - invite major superiors of religious men and women to attend their meetings.

\footnotetext{
50 Carmel McEnroy, Guest in their own house; Mary Luke Tobin, SL, "Women in the Church: Vatican II and after." The Ecumenical Review, Vol. 37 no. 3 (1985:295-305).

Tobin, S.L, Women in the Church: 296.

Carmel McEnroy, Guest in their own house, (169).

Helman, Women and the Vatican:25

Ordinatio Sacerdotalis, John Paul II, 22 May 1994-Apostolic Letter.

ww.vatican.va/.../hf_jp-ii_apl_22051994_ordinatio-sacerdotalis_en... (accessed on 08-09-12).

Gebara, Pope Francis and theology of women: some concerns

56 Brian Roewe, “Australian priest, advocate for women's ordination excommunicated", National Catholic

Reporter, http://NCRonline.org (accessed 2-10-13).
} 
It has been noted that the majority of the Catholic faithful who live a religious life are women; statistically it is recorded that there are three women to every one male religious. ${ }^{57}$ Yet the Congregation for the Institute of Consecrated Life and Societies of Apostolic Life in the Vatican has no religious sister in the hierarchy of its leadership. ${ }^{58}$ Based on such representation it is clear that the power structure and offices within the Catholic Church are dominated by males, which some African Bishops including the clergy have criticized by charging that women need to be recognized and brought in to full participation in the Church and wider society. ${ }^{59}$ The issue is that the male church has intentions of creating safe spaces for women's participation, specifically for religious sisters but do not know how to put theory into practice. Therefore, religious sisters of the $21^{\text {st }}$ century are following in the footsteps of their sisters, including courageous founders of their various congregations and other women who have stood the test of time, to demonstrate that they have a safe space in the Catholic Church as children of God through identification with Christ. In this way, the religious sisters are not waiting for anyone to include or exclude them from full participation in the Church. They do this by owning the Church as theirs and making all things possible to contribute as well as to share in transforming the Church's spaces into safe spaces for themselves and every member of the Church including boys and girls, men and women. This is vivid in the life of many religious sisters who have availed themselves of education (be it secular or theological) as a means of self-empowerment. In particular we look at the life story of three African religious sisters who have engaged with and negotiated the Catholic Church as safe spaces.

\section{Life Stories of Three African Religious Sisters as Case Studies}

Across the globe, Catholic religious sisters have made outstanding landmarks through various contributions in ministry which position them as leaders. They take the lead in providing key services in the fields of education, pastoral ministry, hospital and social care. They provide these services under the auspices of their congregations through the Church and in the name of God. Thus, in this way they construct the Church spaces as safe spaces for the services they render. Apart from the grace of God that strengthens them daily, their energy comes from the power of professionalism which they have acquired over the years and their lives inspire other women. Within the African context there are many religious sisters who have gained professional training either in secular education such as medicine, teacher's education, and engineering, nursing or theological education. For the purpose of this article I have deliberately chosen to look at three African religious sisters who have excelled in theology and have gained the status of prominent professors. These three sisters are selected from different regions of Africa: Sister Professor Anne Nasimiyu Wasike, Lsosf from Uganda, Sister Professor Josée Ngalula, CSC from DRC, and Sister Professor

57 Josè M Arnaiz, JCR Garcia Parades, Camilo Maccise, “The identity of the religious.” In Consecrated Life Today: Charism in the Church for the World (ed.) by Union of Superior General 193-228, Roma: St Pauls (1994:198).

58 Küng, Women in Christianity.

59 Agbonkhianmegbe, Orobator, SJ, The Church as family: African ecclesiology in its social context. Kenya: Paulines Publications Africa (2000); Charles Palmer-Buckle, Ghanaian Archbishop says church has failed Africa, National Catholic Reporter, http://ncronline,org/news/vatican/ghanaian-archbishop-says-church-hasfailed-africa (accessed on 20 October 2010); Elochukwu E Uzukwu, A listening Church: Autonomy and communion in Africa Churches. New York: Wip \& Stock Publications (2006); Peter Appiah Turkson, "Secretary General's closing remark for the Synod Assembly 2009: Hearing the cry of women at the African Synod.” webkeeper@ncronline.org (accessed on June 1, 2011). 
Teresa Okure, SHCJ from Nigeria. These sisters are selected purposively based on their achievements, professional contributions, and inspiration they offer to others. Specifically their life stories will be used as case study to portray how religious sisters of the $21^{\text {st }}$ century are transforming Catholic Church spaces into safe spaces for their self-construction and for others too.

\section{Sr Prof Anne Nasimiyu Wasike, Lsosf}

$\mathrm{Sr}$ Prof Anne Nasimiyu Wasike, Lsosf, is a Catholic religious sister from the Kenya/Uganda province of the Little Sisters of St Francis. Presently, she serves as the congregation's General Superior. She completed her doctoral studies in Systematic Theology at Duquesne University in the USA with specialization on inculturation. She was challenged in this undertaking by her local bishops, both from Kenya and Uganda, who travelled personally to the USA to discourage Sr. Prof. Anne from continuing with her studies. ${ }^{60}$ But she personally resolved to pursue her studies to the end and was encouraged by her mentor at the University. When she returned home after her studies, she received a cold welcome and was not employed by the Catholic University of Eastern Africa - rather she found employment with Kenyatta University in Nairobi and was warmly welcomed in ecumenical circles. Once she was invited by the Catholic University in Nairobi to give an input during a workshop on inculturation and to her greatest consternation her contribution was evaluated - the Bishop present asked a priest who studied inculturation if what she had said was correct, portraying lack of trust in her ability. ${ }^{61}$

In spite of this lack of acceptance among her Catholic peers and particularly from the Church hierarchy, Sr Prof Anne has made tremendous contributions to the field of Theology particularly in the area of inculturation and in representing the voice of women. In a talk delivered at Hekima College, she emphasised that the 'value of the women is the value of the Church' and the main thesis of her speech focused on representing the unique contributions women make. ${ }^{62}$ In her argument, she posited that women are not just custodians of fundamental values of the Church but also inventors of these values, and therefore must be recognised for their worth. In an exclusive interview session with BBC, she identified with the plight of women who face the challenge of unwanted pregnancies: she advocates that the State should legalize abortion when the life of a poor woman is endangered. However, she was sanctioned by the Church for taking such a stand. ${ }^{63}$ She is a renowned professor who has written extensively towards inclusive theology with respect to African culture.

\section{Sr Prof Josée Ngalula, CSC}

Sr Prof Josée Ngalula is a Catholic religious sister of Saint André, from the Democratic Republic of Congo. She received her doctoral degree from the Catholic University of Lyon, France with focus on the evaluation of translation enterprises/activities in the context of

60 This information is based on personal email communication with Sr Anne Nasimiyu Wasike, Lsosf. (4 August 2012).

61 Based on e-mail conversation with Sr Anne.

62 Anne Wasike, (2006). "The value of the women is the value of the Church: from rhetoric to reality" A talk delivered at Hekima College Forum, April 28.

63 Prominent Nun/Professor Formally Repents Reports of Abortion Support... (accessed 1-04-2013). www.lifesitenews.com/Idn/2006/sep/06090708.html 
Christian Mission. She has been a professor of Dogmatic Theology at Saint Eugène de Mazenod Institute since 1994 and at the Catholic University of Congo since $2002 .{ }^{64}$ She has contributed immensely to the Church's biblical apostolate and on-going formation of Lay people. She is a founding member of the Association of African Theologians (ATA/AAT) the Association of Women Theologians and Women Canonists of Kinshasa; she is also a member of Tsena Malàlaka: lieu d'échanges pour théologiennes africaines et européennes (a forum of exchange for African and European women theologians). ${ }^{65}$ She is an expert in Christian Lexicology and Traductology/Translation for African Languages, with special stress on the Missiological incidences. Within her local context, she has created the collection of Bible et Femmes en Afrique.

Sr Prof Josée has written extensively in the area of biblical translation, dogmatic theology, and African feminism. One of her popular arguments is that women need to contribute meaningfully towards re-defining who they are; hence they should no longer wait for men to speak on their behalf. ${ }^{66}$ Essentially, this argument of hers is vital as it provides the opportunity for women to be proactive and no longer passive in constructing safe spaces for their own self-definition. In addition, she advocates for self-development through education for all women and particularly for Catholic religious sisters who are called to be custodians of faith. ${ }^{67}$ For these reasons, she has made an outstanding contribution which facilitates the transformation of the Catholic Church into safe spaces for religious sisters.

\section{Sr Prof Teresa Okure, SHCJ}

$\mathrm{Sr}$ Teresa Okure, SHCJ, is a Catholic religious sister of the African province of the Society of the Holy Child Jesus from Nigeria. She obtained her PhD from Fordham University in New York. She is a professor of New Testament and Gender Hermeneutics at the Catholic Institute of West Africa in Nigeria, where she has served as Head of the Department of Biblical Studies and former Dean of the Faculty of Theology. ${ }^{68}$ She is a well-known biblical scholar and is also a member of various national and international theological and biblical associations. She is a founding president of the Catholic Biblical Association of Nigeria (CABAN). ${ }^{69}$ Sr Prof Okure's publications and lectures have drawn international acclaim and the Catholic Church in Africa has duly recognized her achievement.

She was one of the women who attended the 2009 Second Special Assembly for Africa of the Synod of Bishops. Forthrightly, she positions herself as a full member of the Catholic Church based on her baptism which she advocates should be the attitude of all baptized Catholics. ${ }^{70}$ In her opinion, every baptized Catholic has a right of place and must endeavour to perceive the Church as family as was portrayed by 1994 First Special Assembly for

\footnotetext{
64 Publications de Sr Josée Ngalula, religieuse de saint Andre, theologienne, (accessed 13-08-2012). http://srngalulapublications.blogspot.com (in French). Her achievements were derived from this website. Publications de Sr Josée: http://srngalulapublications.blogspot.com

66 Josèe Ngalula, (2005). Violence against women. Circle News No 5 Frenchweb.P.65. Accessed 02-04-2013 www.thecircleawt.org/...circle+News+No+5+Fre...

67 Josèe Ngalula, (2009). Diakonia and reconciliatory word for Africa abused, p. 331-345. Spiritus (196).

68 Sister Teresa Okure, SHCJ 01.20.11-Trinity Church: Teresa Okure biography... (accessed on 13-08-2012) www.trinitywallstreet.org > Faith Formation > Trinity Institute

69 Duke Newt: Teresa Okure to give 2010 Clark lectures (accessed on 13-08-2012)

dukenewt.blogspot.com/2010/.../teresa-okure-to-give-2010-clark.ht...

70 Personal email communication with Sr Teresa Okure (6 ${ }^{\text {th }}$ August, 2012).
} 
Africa of the Synod of Bishops, where there is equality among family members (cf. Heb. $12: 22-23)^{71}$

In one of her reflections on Luke 8:40-56, she proposed that every woman has "the will to arise" as did the hemorrhaging woman who had the courage to counteract the sociocultural barriers of her Jewish tradition to encounter Jesus and was healed. ${ }^{72}$ In this way, she encouraged other women to be steadfast in challenging the cultural barriers that position them as dependant on others. In a paper delivered at SEDOS seminar, she posited that the role of women in the African Church is paramount, therefore, cannot go unrecognized $^{73}$. As a consequence, she challenged the Church in Africa to give women their rightful place by affirming their contributions to the growth of the Church as well as giving them space to be actively involved in all spheres of its leadership scheme otherwise it runs the risk of losing valuable contributions that women could offer. Recently I was present at a one-day seminar which she presented at Cedara Theological Institute in South Africa, and among other things; she argued that no group of people needed to be sidelined in the Church. She maintained that the voices of everyone needed to be heard and it was only in that way that the Church could reflect the true image of "body of Christ ${ }^{\text {"74. }}$. Significantly, she constructed the Catholic Church space as belonging to all members who ought to work towards continual transformation of the spaces for every member including children and women. Thus, no single member should allow her/himself to be excluded from the Church; it is large enough to take everyone on board.

\section{Conclusion}

The answer to the question: 'Is the Catholic Church a safe space for religious sisters' is multifaceted. On the one hand, there is evidence to prove that religious sisters have not been accorded free space in the Catholic Church in terms of full participation in the Church's ministry, recognition (specifically in terms of freedom to express their views) and access to education, including theological education. This is portrayed in the way that the Church hierarchy - represented by men - has treated women, including religious sisters across the centuries, particularly in the early Church throughout the medieval period and even into the pre and post Vatican II eras. However, on the other hand, the religious sisters themselves are forcefully transforming the Church's space into safe spaces through personal agency based on their understanding that the Church is made up of all baptized Catholics. In this way, they position themselves as true family members of the Church who share the responsibility of on-going transformation within the Church, which will lead the Church to achieve its goal of being a family united in Christ. On this basis, the religious sisters through the ages have presented themselves as in-house critics who will not give-up on the Church. There is no turning back, no matter how long the journey, no matter how many roadblocks and obstacles they might encounter - women religious are focused on

71 Okure, Teresa "What the African Synod means for religious communities in Africa/Madagascar: In reference to reconciliation, justice and peace". A talk delivered to Cluny Sisters during Chapter, Ibadan, Nigeria, May, 2010.

${ }^{72}$ Okure, Teresa (2006). Epilogue: The Will To Arise: reflection on Luke 8:40-56. In The will to arise: women tradition and the Church in Africa edited by M.A. Oduyoye and M.A.R. Kanyoro p.221-230. Pietermaritzburg: Cluster Publication

${ }^{73}$ Okure, Teresa SHCJ. (1993). The role of women in the African Church. SEDOS Seminar, ROME.

${ }^{74}$ Okure, Teresa SHCJ. "Gender Complementarities: A concern for the Catholic Church". Seminar paper presented at St Joseph Theological Institute, South Africa, October 7, 2012. 
claiming their baptismal calling and they invite every member of the Church to do their part in order to ensure that the Church's mission is achieved: that mission, in which every member is accorded the pride of place as a child of God.

\section{BIBLIOGRAPHY}

Abbot, E 1999. A history of celibacy. New York: Harper Collins Publishers Ltd.

Arnaiz, JM, Garcia Parades, JCR \& Maccise, C 1994. How to understand and present religious life today in the Church and in the world. In Union of Superiors General (eds.) Consecrated Life Today. Rome: St Pauls.

Boever, RA 1986. Cameos of Church History. Ligouri, Missouri: Liguori Publications.

Brockman, N 1990. A popular history of religious life. Nairobi, Kenya: St Pauls Publications-Africa.

Flannery, A 1975. Vatican Council II: The Conciliar and post Conciliar documents (ed.). New Delhi: St Pauls.

Fiorenza, ES 1983. In memory of her: A feminist theological reconstruction of Christian origins. New York: The Crossroad Publishing Company.

Fiorenza, ES 1996. The power of naming: A Concilium reader in Feminist liberation theology. Maryknoll, NY: Orbis Books.

Gonzalez, MA 2007. Created in God's image: An introduction to feminist theological anthropology. Maryknoll, New York: Orbis Books.

Helman, I 2012. Women and the Vatican: An exploration of official documents. Maryknoll, New York: Orbis Books.

Küng, H 2001. Women in Christianity. London: Continuum.

Maloney, SM 1995. Historical perspectives on women religious: Implications for creating a feminist theology of religious life. In MA Hinsdale and PH Kaminski (eds.) Women \&Theology. Maryknoll, New York, Orbis Books.

McNamara, JAK 1996. Sisters in arms: Catholic nuns through two millennia. Cambridge, Mass: Harvard University Press.

Ngalula, J 2009. Diakonia and reconciliatory word for Africa abused. Spiritus (p. 331-345)

Okure, T 1993.The role of women in the African Church. A paper presented at SEDOS seminar, Rome, May 18-22.

Okure, T 2006. Epilogue: The Will to Arise: reflections on Luke 8:40-56. In MA Oduyoye and MAR Kanyoro (eds.) The will to arise: women, tradition and the Church in Africa (p.221-230). Pietermaritzburg: Cluster Publication.

Okure, T 2010. "What the African Synod means for religious communities in Africa/Madagascar: In reference to reconciliation, justice and peace. A talk delivered to Cluny sisters during chapter gathering."

Okure, T 2012. "Gender Complementarities: A concern for the Catholic Church". Seminar paper presented at St Joseph Theological Institute, Cedara, South Africa. October 7.

O’Murchu, D 1991. Religious life: A prophetic vision - hope and promise for tomorrow. Notre Dame, Indiana: Ave Maria Press. 
O'Reilly, M 1996. The challenges of being a religious in Africa today. Nairobi, Kenya: Kolbe Press.

Orobator, AE 2000. The Church as family: African ecclesiology in its social context. Nairobi, Kenya: Paulines Publications Africa.

Papal Encyclical 1976. Inter Insigniores: Declaration on the question of admission of women to the ministerial priesthood.

Po-Chia Hisa, R 1998. The world of Catholic renewal 1540-1770. Cambridge: Cambridge University Press.

Pope John Paul II 2005. Dignity and Vocation of Women: Apostolic letter, Mulieris Dignitatem of John Paul 11. Nairobi, Kenya: Paulines Publications Africa.

Rakoczy, S 2004. In her name: Women doing theology. Pietermaritzburg: Cluster Publications.

Ruether, RR 1987. Contemporary Roman Catholicism: Crises and Challenges. Kansas City, MO: Sheed and Ward.

Schneiders, S 2011. Prophets in their own country: Women religious bearing witness to the Gospel in a troubled Church. New York: Orbis Books.

Schneiders, S 2000. Finding the treasure: Locating Catholic religious life in a new ecclesial and cultural context. New Jersey: Pauline Publications.

Tobin, ML 1985. "Women in the Church: Vatican II and after."The Ecumenical Review. Vol. 37 no. 3.

Tuttle, L 2010. "From cloister to court: Nuns and the gendered culture of disputing in early modern France." Journal of Women's History 22, (2) 1-42.

Uzukwu, EE 2006. A listening Church: Autonomy and communion in Africa Churches. New York: Wip \& Stock Publications.

Wasike, A 2006. "The value of the women is the value of the Church: from rhetoric to reality." A talk delivered at Hekima College forum, April 28.

\section{Internet Sources}

Apostolic Letter, Novo Millennion Ineunte of his Holiness Pope John Paul II to the Bishop's Clergy and lay Faithful. Retrieved from www.vatican.va/.../john_paul_ii/.../hf_jp-ii_apl_20010106_novo-mil (accessed 07-08-2012).

Gebara, I 2013. Pope Francis and the theology of women: some concerns (English translation by Rebel Girl). Retrieved from http://iglesiadescalza,blogspot.fr/2013/08/pope-francis- and-theology-of-womensome.html (accessed on 12-08-2013).

Joan of Arc, Retrieved from brief biography archive. joan-of- arc.org/joanofarc_short_biography.html (accessed on 15-08-2012).

Marguerite Porete - The mirror of simple souls. Retrieved from www.margueriteporette.org/ (accessed on 15-08-2012).

McKew, M. “Augustine on women: De Trinitate, 12, 7, 10" Retrieved from heritage.villanova.edu/vu/heritage/allthings/2001SU.htm (accessed on 04-07-12). 
Ngalula, J 2005. Violence against women. Circle News No 5 Frenchweb, p.65. Retrieved from www.thecircleawt.org/...circle+News+No+5+Fre. (accessed 02-04-2013).

Palmer-Buckle, Charles, Ghanaian Archbishop says church has failed Africa, National Catholic Reporter, Retrieved from http://ncronline,org/news/vatican/ghanaianarchbishop-says-church-has-failed-africa (accessed on 20-10-2010).

Publications de Sr. Josée Ngalula, religieuse de saint André, theologienne. Retrieved from http://srngalulapublications.blogspot.com (in French) (accessed on 13-08-2012).

Roewe, B. “Australian priest, advocate for women's ordination excommunicated”, National Catholic Reporter, Retrieved from http://NCRonline.org (accessed on 2-10-13).

Sister Teresa Okure, SHCJ 01.20.11-Trinity Church: Teresa Okure biography. Retrieved from www.trinitywallstreet.org > Faith Formation > Trinity Institute(Accessed on 13-08-2012).

Turkson, PA “Secretary General's closing remark for the Synod Assembly 2009: Hearing the cry of women at the African Synod." Retrieved from webkeeper@ncronline.org (accessed on June 1, 2011). 